\title{
THE RITE OF MALE CIRCUMCISION AMONG THE MUSLIM POPULATION IN THE WESTERN BALKANS
}

\author{
Alexander Novik \\ PhD \\ Head of the Department of European Studies \\ Peter the Great Museum of Anthropology and Ethnography (Kunstkamera) \\ Associate Professor \\ Saint Petersburg State University, Russia \\ njual@mail.ru
}

\begin{abstract}
The article deals with the rite of circumcision among the Muslims in the Western Balkans, one of the most widespread ritual practices, held with some variations mostly at the age of 3 to 7 . The tradition that never gets explicitly brought up in the sacred text of the Quran has become practically mandatory. Among the rites of passage, circumcision is considered by Muslims a significant act, as it symbolizes the transition from the status of a child to the status of an adult who has all the rights of a "full-fledged" man. In the Balkan Muslim community, an uncircumcised man is regarded as an exception to the rule.

In the second half of the twentieth century, the technical side of the rite was radically changed, but it has not affected its sacred and traditional elements. Nowadays, in its origins, its religious roots, its folk depictions and its place in the relations between "us" and "them", the circumcision ceremony is a rite of initiation and is one of the most remarkable ritual practices that demonstrates committal to Islam. The article is mainly based on the actual field data gathered by the author in Albania, Kosovo, North Macedonia, Montenegro, and other countries of the region during the last three decades.
\end{abstract}

Keywords: Albanians, Balkan Muslims, beliefs, circumcision, customs, folk Islam, folk medicine, innovations, interpretations of traditions, rites of passage, ritual practices

\section{INTRODUCTION}

For a long time circumcision has been one of the most persistent ritual practices among many peoples of the world. Representatives of particular religions - first of all, Jews and Muslims - do not consider the rite of circumcision one of the main conditions of accepting the fundamentals of the faith (though, for example, 
the text of the Quran does not explicitly mention the necessity of circumcision for a righteous Muslim) (The Noble Qur'an; Denny n.d.). On the Balkan Peninsula, circumcision spread widely due to the Ottoman invasion and the local ethnic groups' conversion to Islam in the fourteenth-seventeenth centuries. Currently, the Balkan people view this rite not just as a sign of adherence to Islam, but also as a part of tradition, a rule established by their ancestors and therefore mandatory (Xhagolli 2008: 21-37).

The aim of the current study is to analyze the perception of the rite of circumcision by the peoples of the Western Balkans, particularly the Albanians of Albania, Kosovo and North Macedonia, with data from other ethnic groups (predominantly Muslims as well as Orthodox and Catholic Christians). It is very important, in my opinion, since over the last few decades there has been an increase of influence of the radical forms of Islam, with attempts of spreading the practices that are not traditional for the Balkan regions, such as female circumcision. I am focusing on male circumcision, which is considered a traditional practice in the Balkans - as opposed to the foreign rules and stereotypes introduced from the outside (cf. Elbasani \& Roy 2015).

The rite of circumcision is one of the main rites of passage that symbolize the transfer from the status of a child to the new status of an adult (in this case, of course, it is a matter of confessional rather than biological age). The boy's initiation marks the border between childhood and adult life - the rite signals that the Muslim community has just become bigger and now has a new member (Çoçaj 2012: 15-17).

So far there have been no studies on this particular topic (except for the few papers dedicated to details of the festivities surrounding the rite). Together with Yefim Rezvan, we have developed a pilot project of research of Islam in the Balkans, which also includes the topic of circumcision (Novik \& Rezvan 2019: 119-153). The main goal of the project is the study of beliefs and ritual practices of the so-called folk Islam (other term: popular Islam) with the aim of discerning mechanisms of preserving and passing on traditions in the spiritual and material spheres of people's life.

This study is mainly based on the fieldwork I carried out in the Western Balkans in 1990-2019, as well as the analysis of ethnographic, folklore, and historic records preserved in the archives of the Institute of Cultural Anthropology and Art Studies (Tirana), the Institute of Linguistics and Literature of the Academy of Sciences of Albania (Tirana), and the Institute of Albanian Studies (Pristina). The main methodological principles underlying the study are the descriptive, typological, and comparative approaches. The principal methods employed here are structural and functional analyses. A historical approach allowed me to reveal the main strands of the genesis of the circumcision custom and the evolution of the old ritual practice until today. 


\section{HISTORICAL AND THEORETICAL OVERVIEW OF THE TOPIC}

The circumcision of an orthodox Muslim (khitan, Arabic: ختخ; khatna, Arabic: Tتخ; sunnat - an Islamic term for circumcision) is one of the main demands of Islamic teaching in most of the world's region (Wensinck 1986: 20-22). In the modern practices of the Balkan peoples this religious custom is observed almost unfailingly.

In human history, we can find very early instances of the circumcision practice (Gennep 2004 [1909]: 69-72). There are different versions of the practice's origins, which usually explain the practical significance of the procedure from the hygienic aspect. This operation involves the surgical removal of the foreskin from the male genitals, which leaves the head open (Circumcision n.d.). The absence of the foreskin contributes to the cleanliness and does not demand as much care for the penis as in the case of uncircumcised men. According to various authors, this fact has contributed to the tradition of circumcision spreading among different peoples at the early stages of human history.

On the other hand, many anthropologists claim that the practice has been established not because of hygienic cleanliness, but in accordance with the ideas of religious cleanliness - the openness of genitals, in the opinion of priests and others who had "the connection to higher powers", led to the openness in the conversation with gods (Xhagolli 2008: 21-37).

We can give a great deal of examples of the tradition of circumcision in the past and present (Gennep 2004 [1909]: 69-72). However, we cannot discern any general tendencies. In any case, both main versions of the origin of circumcision have their weak points as well as strengths. For example, not all peoples of the world have this tradition, which means that circumcision is not a definite cultural, civilizational, religious or social universal. History has recorded cases when peoples who have practiced circumcision for a long time later give up the tradition (for example, the Armenians, who had practiced it as far as the end of the first millennium AD) (Karpov 1996), while others, on the contrary, acquire this tradition as an innovation, dictated by religious demands or matters of cleanliness and hygiene - anyway, it is an influence of factors of social fashion, which sometimes changes traditional institutions, lifestyles, and customs.

Different religions of the world have different approaches to circumcision.

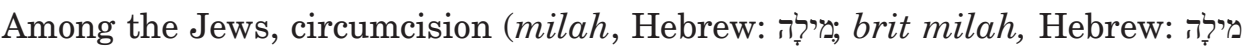
, li: literally 'testament of circumcision') is one of the main rites of initiation to the faith (Oren (Nadel') \& Prat 1992). In Christianity circumcision is neither a mandatory nor a recommended rite (though the Christian church calendar has the feast of Circumcision of Christ ${ }^{1}$ ). In most of the schools of Islam circumci- 
sion is a mandatory rite. In Hinduism, circumcision has not been recorded. For Buddhists, circumcision is optional - the religious teachings do not demand it.

In the modern world, many peoples in the Old as well as in the New World have adopted circumcision as a tribute to the demands of medicine, new fashions, and tendencies in cleanliness. ${ }^{2}$

Currently, the situation with circumcision practice, in accordance with religious and medical demands, is different worldwide: for example, there are countries and territories where 99.8-99.9 percent of men are circumcised (Afghanistan, Tunisia, Morocco, the West Bank, the Gaza Strip); by way of comparison, in Russia 11.8 percent of men are circumcised (for statistics on male circumcision in 237 countries and territories of the world, as of April 2016, see Novik \& Rezvan 2019: 122).

As mentioned above, circumcision has religious significance among the Muslims. In the opinion of most of the Muslim spiritual leaders, circumcision opens the believer's path to Allah. However, it is important to remember that Sunnah first appeared almost fourteen centuries ago, on territories with hot climate and limited water resources, and at that time maintenance of physical cleanliness simply guaranteed survival in the desert. This is why both the Quran and the Muslim sacred tradition fairly often refer to the topic of cleanliness - physical as well as spiritual. ${ }^{3}$

\section{CIRCUMCISION RITE IN THE BALKANS: THE POWER OF TRADITION AND/OR A SYMBOL OF FAITH}

The Muslims of the Balkan Peninsula practically unfailingly observe the instruction to perform the rite of circumcision - it is viewed by the majority as the act of adopting Islam (here we are talking about the views of the folk Islam - the beliefs and practice spread among the general public). Circumcision is one of the main rites of passage, held usually at the age of 3 to 7 with some variations (Gennep 2004 [1909]: 69-72; Xhagolli 2008: 21-23), during which a boy is transferred from the condition of uncertainty (first of all, confessional uncertainty) to the world of adult Muslim men-believers. This event is so significant in Islam that many peoples of the Balkan Peninsula view it as one of the main events in human life. In Albanian, the circumcision rite is called dásma e vogël 'little wedding', which is a sign of the event's high status not just from the religious standpoint, but also from the social one, for a large circle of relatives and acquaintances, often from the entire $f s^{4}$ and krahina ${ }^{5}$. A sumptuous ceremony is hosted for that occasion, with invitations for the numerous relatives, neighbors, friends, etc. Traditionally it has been a rite to which the 
imam or the mullah is invited. After the completion of the circumcision, there is a generous feast for the guests, where the menu is as carefully arranged as the dishes for an "adult" wedding. Often the guests take a ride around the town or the countryside: a cavalcade of cars, decorated for such an important and happy occasion, goes around the neighborhood to the sound of horns and loud music, to let the countrymen know that the Muslim community has grown another man has become a full-fledged member of the Islamic society, and the belief in Allah lives on (Novik \& Rezvan 2019: 125).

The family begins to prepare for the circumcision ceremony in advance besides the cooking and the invitation of relatives and friends, a special set of clothes - the so-called "sultan's attire" - is bought to the boy who is going to be circumcised (see Fig. 1). It consists of a wide shirt, wide trousers, a cloak and an essential head-dress with a plumage. This tradition is relatively new in the Balkans; it has become widespread in the last 30 years.

Figure 1. Showcase of a children's clothing store with a costume for the rite of circumcision. Ferizaj, Kosovo. Photograph by Alexander Novik, August 2011.

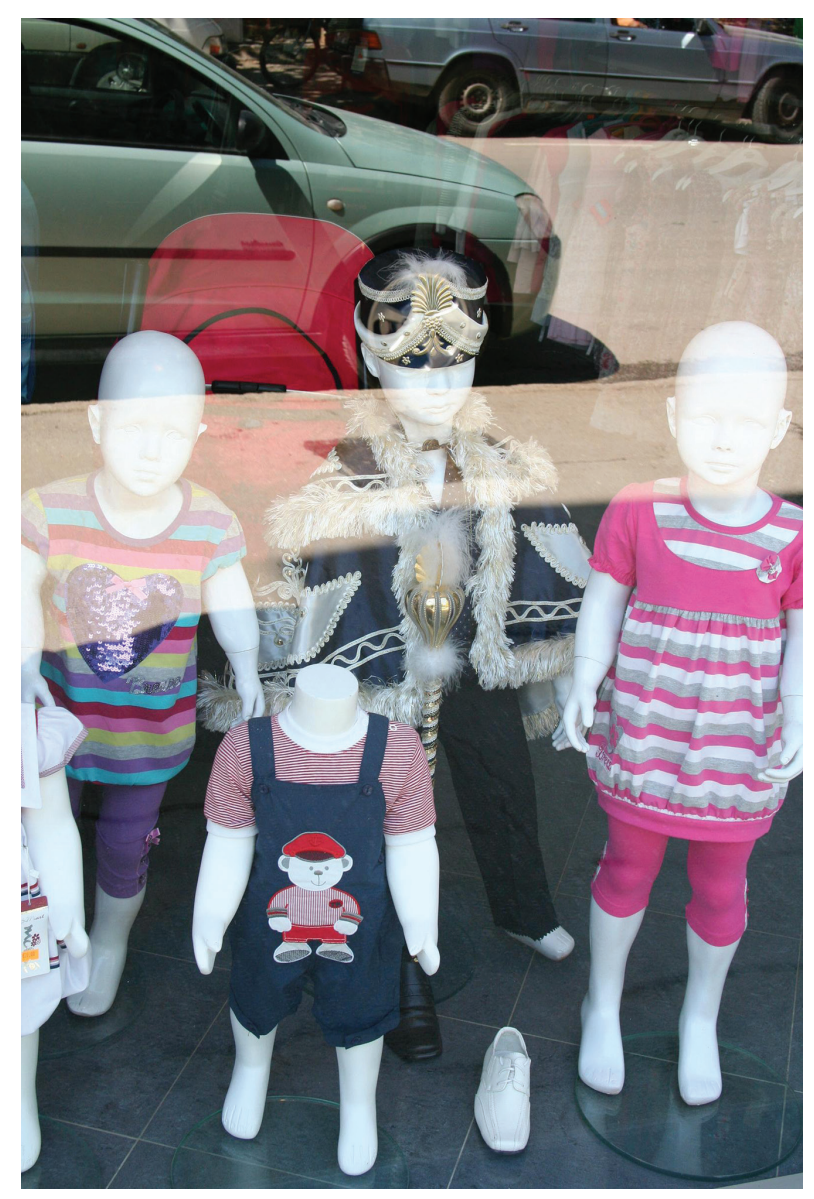


The age at which boys undergo the circumcision rite varies across South-Eastern Europe. There are no specific regulations on that subject as long as an adult Muslim man is circumcised. In modern Turkey circumcision is performed on infant boys - practically in the first months or often days of their life (the same practice is recorded in the Western countries, where the operation is viewed as a medical and hygienic necessity rather than a religious ceremony). In Albania, Kosovo, North Macedonia, Bosnia and Herzegovina, Serbia, Montenegro, and Bulgaria circumcision can be performed on boys under ten - when the ceremony gets performed at an older age, it is viewed by the others as late (the medical data should also be taken into account here: the child's body is already maturing and reacts more painfully to the operation). On rare occasions the parents delay the ceremony, and the grown children, out of their fear of surgery, flatly refuse it. A young man who remains uncircumcised would later hide the fact from his equals in age and the broader audience rather than announce it (Xhagolli 2008: 30-35).

In Albania, Kosovo, North Macedonia and other countries the ceremony of circumcision is usually performed when boys reach the age of 3-7 years. When a family has several sons close in age, the parents would frequently circumcise them all on the same day - this way, they save money on organizing the feast for the guests invited for the occasion (such feasts can sometimes bring ruin to people with a small income) (AMAE: Novik 2013; Novik 2017: 126-127).

Till the middle of the twentieth century, the circumcision ceremony was performed by imams, mullahs or khojas in villages and towns. As a rule, experienced religious workers, who had skills in conducting such operations, were asked to do it. They had the appropriate instrument - a well-sharpened knife, a straight razor or a special blade. These instruments were used exclusively for the operations that held a sacral meaning. For the treatment of the wounds the religious workers also used the medicines (brewed herbs, salves, etc.) and available materials (tissues, bandages, garters) that they were accustomed to and that were approved traditionally. In Bosnia and Herzegovina, for example, in Sarajevo, for several decades after the Second World War circumcision was still performed by barbers (Serbian, Croatian, Bosnian, Montenegrin: бépбер / bérber < Turkish: berbér). The performance of the operation was part of their professional skills and brought them virtually more money than the rest of their job. As the long-present trade system of the city collapsed, the berbers retained their establishments, getting a steady income for this procedure (Novik \& Rezvan 2019: 127).

In Albania, during the years of the communist dictatorship, which is here called the period of monism, conducting religious ceremonies was strictly forbidden. However, circumcision was performed "secretly" - not as a ceremony 
demanded by belief in Allah, but as a medical operation motivated by hygienic concerns. Boys were circumcised by surgeons in hospitals under the guise of "medical necessities", and at home the parents of the newly circumcised made a feast for their relatives and close friends, whom they trusted not to give them away to the authorities for a covered-up performance of a Muslim ceremony.

During the past decades, since the 1980s, circumcision operation has been performed in medical establishments in most Balkan countries. There are applications to surgeons in private as well as in public clinics. Nowadays one of the most frequently encountered advertisements in Kosovo is the announcement that this or that hospital or private clinic performs circumcision (Fig. 2). In most cases the boy is brought to the hospital by his parents (usually the father and one of the relatives). The surgeon operates using medical instruments and local anesthesia (painkiller injections, etc.). No prayers are said in this case (and the surgeon does not even necessarily need to be a Muslim). After the operation the surgeon swabs the wound with an antiseptic salve (most often it is brilliant green) and gives the parents recommendations for its treatment for the first days or weeks after circumcision. The family returns home and hosts a celebration for friends and relatives.

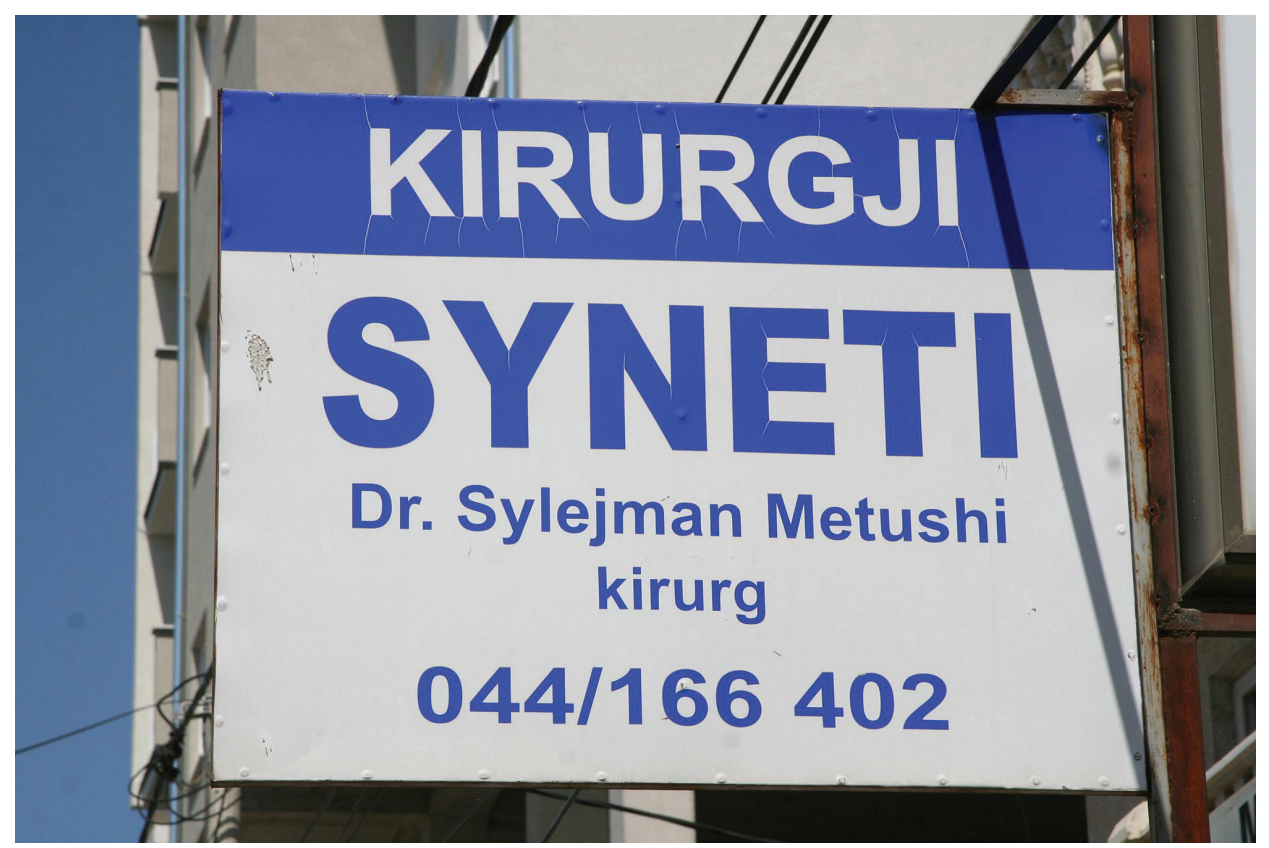

Figure 2. Signboard of a surgical clinic offering circumcision services. Ferizaj, Kosovo. Photograph by Alexander Novik, August 2011. 
In the Muslim community of the Balkans, an uncircumcised man is considered an exception from the rules: Tek ne pa synet janë vetëm të krishterë, ateistë dhe fukarenj - ata nuk kanë páre për kët gjë (Albanian, dialectal: 'Among us, the uncircumcised are only Christians, atheists and paupers - they do not have the money for it's).

In modern Albania, there are still the stories that after Skanderbeg's ${ }^{7}$ death the Turks, ultimately unable to convert the entire population of the country to Islam, ordered men, regardless of their faith, to be circumcised, as a sign of their loyalty to the sultan. ${ }^{8}$ Nevertheless, on most of the territories where the Albanians live, circumcision is viewed as a purely Muslim prerogative - a vast majority of the Orthodox and the Catholics do not perform this operation. The same can be said about the Slavic population of the Balkan Peninsula: circumcision is recorded among the Bosnians, the Gorani (a Muslim ethnic group inhabiting the Gora region - the triangle between Kosovo, Albania, and North Macedonia), the Torbeši (Macedonian Muslims), the Muslims of Montenegro (the Mrković/Mrkojević tribe), the Pomaks in the Rhodope Mountains (Bulgaria), the residents of Sandžak, etc., who practice Islam. The Southern Slavs, who practice Christianity in the form of Orthodoxy or Catholicism, or any other religion apart from Islam, regard circumcision as a marker of belonging to the Muslim community (Fig. 3).

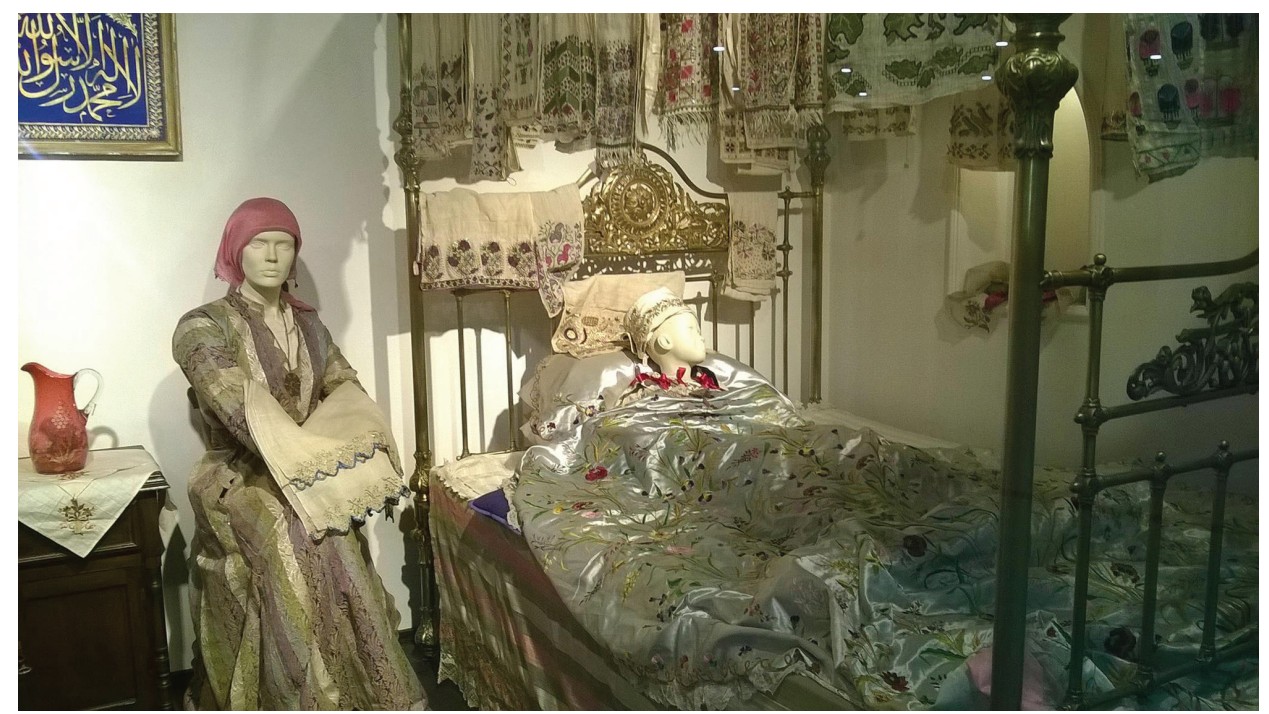

Figure 3. Ethnographic exposition "The Custom of Circumcision". Estergon Castle Turkish Cultural Center, Ankara, Turkey. Photograph by Alexander Novik, November 2019. 


\section{INNOVATIONS VS. "IT IS NOT OUR WAY"}

Though male circumcision is almost obligatory among the Balkan Muslims, female circumcision has almost never been recorded there. In various other regions of the world this type of religious practices are described fairly well (Nussbaum 2000 [1999]). Female circumcision ${ }^{9}$ is recorded in Africa and Oceania; it used to spread in the Caucasus ${ }^{10}$ and elsewhere. Among different hypotheses, the following explanation of the origin of this practice has been suggested. During male circumcision, according to primitive beliefs, the foreskin of the genitals was removed and the head was left open - therefore, the parts that (in the opinion of the authors of the hypothesis which I do not share) looked like female labia were removed and the man was free of "female atavisms" (Novik \& Rezvan 2019: 131). Meanwhile, during female circumcision a special instrument (usually a sharpened wooden spade) was used to dissect the clitoral glans, which was viewed as an underdeveloped male genital organ remaining on a woman's body. Whatever the case, many ethnic groups still retain the practice of what they call female circumcision (Shell-Dunkan \& Hernlund 2004).

In many regions, especially in Africa, female circumcision has always been a more complex operation - it involves the removal of both inner and outer labia. In ancient Egypt female circumcision was a very widespread practice, and it is still performed on the territory today. Thus, in Egypt, according to statistics, up to 85 percent of women are circumcised. Over the last years, both the Egyptian society and the world press have raised voices against the barbaric tradition, but so far these protests have had no effect on the number of girls subjected to the procedure (Female genital mutilation 2020).

On the Balkan Peninsula, most Muslim believers have not even heard of female circumcision (even though extremist views and practices connected with them have lately found many followers there). For this reason, interviews on this topic were conducted only in a very delicate manner during fieldwork with the town and village population (there were only questions such as: Do you know about female circumcision? When did you find out about the existence of such a practice? Where is this rite recorded? etc.). The analysis of field materials shows that only a small number of the informants (not more than 10 percent) know anything about this practice. Usually the recorded answers are: "What, can you circumcise a woman? What can you even cut from her?"; "Nothing of this sort has even existed in our place. We've never even heard of it, not just in the village, but even, say, in town" (AMAE: Novik 2013; AMAE: Novik 2015; FWMA 1987, 2009, 2014, 2015, 2016, 2019). People living in towns (Tirana, Durrës, Pristina, Prizren, Skopje, Ohrid, etc.) demonstrate a better knowledge of the topic of female circumcision than village residents. It can be explained 
by a higher level of urban residents' education, their wider knowledge of events in their country, region, and the world, and wider informational connections. Often the answers of urban residents include opinions such as: "We don't have such a tradition. Now the Arabs are building mosques around here. Maybe they have it. But it has not reached us yet"; "We learned of it when the refugees came, but it's an unheard-of thing for us". The following interview fragment is rather significant, in my opinion:

Lately, we have had an increase of Muslim influence. Saudi Arabia builds all our mosques. It also forces its values on us. Albanian women have never worn shawls, wrapped up completely. It was only in the sultans' time. Under Enver, women served in the army! With machine guns! What hijabs? Now it's coming back to us. But that's not because the Albanians became very strong believers. Just... because of the poverty. Many families are poor. They go to the mosque. And they say to them: here is money for you, but for that your women must wear hijabs and dress in the Muslim fashion. They pay them 200000 leks (in the old money), that's almost 200 euros a month. So women in that family begin walking around dressed in that Muslim fashion. But that's only how they look in the streets, and at home they walk around with bared bellybuttons! It's all for show!

And what's that female circumcision? There, before the Pope of Rome's visit, just a day before, they arrested 29 imams in Kosovo! They said they were preparing extremists there. They studied in Egypt, in short, in the Near East. Maybe they were preaching about female circumcision too. But our people won't accept much of this. That was in Kosovo. And it's more so in Albania! Here, the relatives won't allow to do what hasn't been done in the family! ${ }^{11}$

There have been attempts to introduce female genital mutilation in the west of the Balkans, mainly connected with the refugees that arrive in the region on their way to the wealthy countries of Western Europe. But these attempts have caused violent opposition and revulsion among the local population. In any case, the rite of circumcision among Balkan Muslims is firmly associated with the rite of male initiation and is viewed as an important stage in a man's life.

\section{INTERPRETATIONS OF THE RITE OF CIRCUMCISION}

In the folk Islam the tradition of circumcision can be interpreted differently. Some members of the Muslim culture explain this tradition with several reasons that contributed to the building of the widespread practice. According to 
the folk beliefs, a circumcised young man, compared to his uncircumcised agemates, has his sexual awakening at an earlier age, and it contributes to his maturing on the whole, the wish to enter an intimate relationship and have a wife and a family. That is to say, the circumcision practice aids the creation of Muslim families at a young age, the birth of more children - the loyal servants of Allah and the spiritual and secular powers and leaders, who were the ones that contributed in many ways to the scrupulous observance of this tradition (cf. Xhagolli 2008: 21-37).

At the same time, other folk explanations of the circumcision practice are recorded - they also are directly linked with sexuality and united in the idea of having as many children as possible.

A circumcised man has a larger penis. Well, if not larger, then thicker - the foreskin doesn't prevent it from getting thicker. The others, the Christians, are different. Our tradition's the right one. It's better for the family line to continue. ${ }^{12}$

When you're circumcised, you can perform longer during intercourse. Because the skin is less sensitive - it happens like that. A circumcised penis always touches something, the clothes, the underclothing. That's why it demands more time for the intimate act, the arousal and the sex. And the uncircumcised one - it's protected by the foreskin. That's worse for the intercourse. The uncircumcised have it quick. We Muslim men are better fit for intimate relations. That's why we have more children, too. ${ }^{13}$

Such explanations, as field data demonstrates, are recorded in the Muslim communities not only in the Balkans, but also in the Caucasus region, Central Asia, the Near East and Northern Africa.

There have been new interpretations not just of the religious and pragmatic elements of circumcision, but of the practices accompanying it, which are closely related to the ritual cycle of life, festive culture, everyday customs, moral stereotypes, family relationships, folk medicine etc. - the complex that comprises the cultural code of Balkan Muslims.

We have a large family. When my brothers and I were circumcised, it was a reason to gather everyone. It was an expensive feast for our family. That's why the parents delayed the rite, so that we would all have it on the same day and they won't have to celebrate the circumcision of each of the brothers. We have a tradition of inviting all the friends and relatives. The family prepares the food, and the guests bring presents. Now they only give money. The closer the relative, the more money he has to give. If it's an uncle, they expect a large sum. And if it's some distant relation, he can give little. The rite is when you can see how others view you. 
What does the present-giving look like? My brothers and I were lying in a room. Grown-ups came in one by one. Only the men come in. Women don't participate in it. They came to us one by one and saw if we were circumcised. Afterwards they left us money. It's a special rite-making sure that the circumcision was performed. And then they continued to celebrate - everybody, both men and women.

In the end, we didn't receive that much money. I got maybe 40 euros. And the celebration costs a lot. ${ }^{14}$

This narration excellently shows the traditional nature of the celebration and the family solidarity - the rite is a consolidating factor. As a rule, even when it comes to obviously innovational phenomena and facts, Muslim believers tend to note the elements of legacy that unite them with the ancestors' customs.

For example, among the Muslims of Albania and Kosovo, chamomile infusion is used to treat the wound after the surgery (Novik 2017: 116-131). As noted earlier, the rite used to be performed by an imam or mullah from the village or the city, and some barbers also specialized in performing the operation. In the past few decades, practically the entire Muslim population of Albania, Kosovo, North Macedonia, and Montenegro has asked doctors in private or public hospitals to perform the traditional rite. The circumcision is performed by a surgeon who uses both modern surgical equipment and the newest anesthetics. After the operation, there is a period of recovery, when one needs to watch over the wound, to avoid infection, etc. As a rule, this process is controlled by the new Muslims' mothers. The doctors themselves advise them to use chamomile infusion. ${ }^{15}$ In the society's eyes, this fact legalizes inviting a qualified doctor rather than an imam, since the following actions with using herbs for treatment support the tradition several centuries long.

My brothers and I were circumcised on the same day; it happened because for economy's sake the parents figured out how to organize it simultaneously for all the brothers. The doctor did the circumcision very quickly; he had that instrument, a scalpel or something like a scalpel. And then he smeared it with some green stuff. So that the wound won't hurt. But it didn't hurt anyway ...

And then we lay in bed at home, each of us in their own bed. First they put a shoe box to the ... so that the wound didn't touch the blanket ... And Mom came to us and moistened the wound with chamomile tea. How did she do it? She just took a bag of chamomile tea, a simple one from the shop, brewed it, let it get a bit cooler. Then she took some wool, dipped it in the tea and moistened the wound... She did it for a week, 
once a day. And then she stopped. It didn't hurt, and there was nothing. That's traditional for us. ${ }^{16}$

As we can see from the interview fragment above, nowadays even simple packaged chamomile tea, sold in corner shops, is used as a medicine - many women do not even go to a pharmacy to buy a medical infusion, which is more suitable for the purpose. In the rite of circumcision, this normal medical practice has entered the sacred sphere, ideologically "shielding" the inevitable innovations in the modern technological society that enter the religious and ritual life.

The Muslims in the west of the Balkans demonstrate a more conservative mindset in their religious practices, everyday customs, and family relationships than members of other religious groups (both anthropological studies and sociological surveys show it). The sphere of tradition is usually associated with the sacred among them, so we can freely state that many features and elements are part of a continued tradition several centuries long.

\section{CONCLUSIONS}

Circumcision is one of the most widespread ritual practices among the Muslim peoples of the Balkan Peninsula. Historically, male circumcision spread in the region after the Ottoman invasion in the fourteenth-sixteenth centuries. The Islamization of part of the Southern Slavs, Albanians, and Eastern Romance people led to the practice of circumcision taking root and gradually becoming perceived not just as a tribute to the religious identity but as a cultural norm. The tradition that never gets explicitly brought up in the sacred text of the Quran has become practically mandatory for the Balkan Muslims as well as for most Muslim communities over the world.

During different periods, normative acts of secular and religious authorities, everyday culture of the referent groups, consisting mostly of new converts, have considerably influenced the ritual practices. The practice of circumcision that originates from the East also affected non-Muslims during a particular period in several regions of the West Balkans (such as southeast Albania and Kosovo). However, most people strongly associated circumcision with belonging to the Muslim community; moreover, considered it practically the main act of conversion to the faith. In any case, I have recorded extensive evidence of the fact that most of my informants view circumcision as a more important act than the rite of initiation of a child/adult into the Muslim faith (which is performed by an imam, mullah or khoja, and is obligatory). 
Among the rites of passage (Gennep 2004 [1909]; Sedakova 2007), circumcision is considered by Muslims one of the main ones, as it symbolizes the transition from the status of a child to the status of an adult who has all the rights of a "full-fledged" man - even though circumcision can be performed at an early age. This role of the rite is evidenced in the terminology. For example, in colloquial Albanian circumcision is called dásma e vógël 'little wedding', which shows the important status of the event not just from the religious aspect, but socially as well, for the wide circle of relatives and often the entire local community. Only a circumcised man is considered an adult, all the exceptions are viewed as marginal.

In the second half of the twentieth century, the technical side of the rite was radically changed, but it has not affected its sacred and traditional elements. Instead of the customary practice of circumcision, performed by imams and barbers before the $1950 \mathrm{~s}$, in the past 70 years it has been recorded, with increasing frequency, that the operation is performed by professional surgeons. This way, the prayers, earlier obligatory, are not read, the accompanying speech formulas are not pronounced, etc. However, despite the intrusion of modern medicine into the sacred sphere, there has been no refusal of traditional folk remedies - first of all, because of the popularity of medical herbs due to the global admiration of ecologically safe food. For that reason, after the operation is performed at a hospital, mothers usually continue to treat their sons at home, using traditional medicines - infusions of chamomile, celandine, etc.

\section{NOTES}

1 The Orthodox celebrate the feast on the 14th of January. The Circumcision of Christ, according to the teaching of the Church, is included in the calendar as the celebration of when "on the eighth day after His Nativity Jesus Christ received circumcision. On that day, He was given the name of Jesus" (Prazdnik 2006).

2 During the past fifty years, this operation has been covered by medical insurance in the USA (along with appendix and gland removal), and many parents wish to receive additional medical treatment without financial expenses. Currently, more than 50 percent of men in the USA are circumcised. The popularity of circumcision is also influenced by the information, based on survey results and given by many medical centers, that circumcised men are less at risk of contracting AIDS and other diseases (Krieger 2012: 3-13).

3 This is why critics of Islam point out the overly "physiological" nature of Muslim holy texts. 
4 Fis (Albanian: $f i s,-i$ ) - a tribal group among Albanians, "considering themselves relatives by the male line. They come from one ancestor, observe exogamy" (Ivanova 1973: 65; Novik 2016: 610-612).

5 Krahína (Albanian: krahin/ë, -a) - historical and ethnographic region in the Albanian lands (Zojzi 1962: 16-64).

6 Recorded in August 2015 from an Albanian Muslim Sunni, 26 years old, born in Pristina, Kosovo, lives in Switzerland (AMAE: Novik 2015: 16-18).

7 Gjergj Kastrioti (1405-1468), known as Skanderbeg (Albanian: Skënderbej or Skënderbeu), was an Albanian nobleman, politician and military commander, who led a rebellion against the invasion of the Ottoman Empire.

8 These folklore stories and legends are reflected in modern fiction (for example, in the works of Ben Blushi (b. 1969)) (Blushi 2008). However, historical facts confirming this information have not been recorded.

9 In different Balkan languages no separate term for female circumcision has been adopted. In the Western countries, there has been a fight against this practice since the 1980s. Thus, in international medical and human rights communities (such as the World Health Organization and the UN) the term 'female circumcision' is tabooed. Instead, terms such as 'female genital mutilation' (FGM) and 'female genital cutting' (FGC) are used. Moreover, the UN has established the International Day of Zero Tolerance for Female Genital Mutilation, celebrated on the 6th of February (Zero Tolerance n.d.; see also Female genital mutilation 2020).

${ }^{10}$ Over the past few years, due to the influence of radical religious propaganda, a spread of female circumcision practice has been detected in Dagestan. Many secular communities and human rights organizations try to fight it, along with many priests who are firm opponents of the "medieval" custom (Karpov 2001).

${ }^{11}$ Recorded in September 2014 from an Albanian Muslim Bektashi, 51 years old, born in Këlcyra, Albania, lives in Durrës (FWMA 2014).

12 Recorded in Ukraine in August 1987 from a Tajik Muslim Sunni, 26 years old, born in Leninabad/Khujand, Tajikistan, lives in Tajikistan (FWMA 1987).

${ }^{13}$ Recorded in August 2010 from an Albanian Muslim Sunni, 18 years old, born in Peja/ Peć, Kosovo, lives in Pristina, Kosovo (AMAE: Novik 2010).

${ }^{14}$ Recorded in August 2013 from an Albanian Muslim Sunni, 21 years old, born in Peja/ Peć, Kosovo, lives in Pristina, Kosovo (AMAE: Novik 2013).

${ }^{15}$ Chamomile infusion (Chamomillae Flos L., Matricaria chamomilla L., Compositae family; Albanian variations of the name: kamomíl, $-i$, maráq, $-i$ ) is traditionally used by the Albanians to treat an entire number of diseases - eye diseases, swelling, wound disinfection (Novik 2017: 116-131). The medical uses of chamomile have been recorded among the Albanians both in the first surviving descriptions of folk medicine and in modern times (Sulaj 2013: 131-133).

${ }^{16}$ Recorded in August 2013 in Pristina from an Albanian Muslim Sunni, 21 years old, born in Peja/Peć, Kosovo, lives in Pristina, Kosovo (AMAE: Novik 2013). 


\section{REFERENCES}

Blushi, Ben 2008. Të jetosh në ishull. [To Live on an Island.] Tirana: Shtëpia Botuese "TOENA".

Çoçaj, Nexhat 2012. Hasi - enciklopedi etnokulturore. [Has - Ethnocultural Encyclopedia.] Vol. IV: Ritet e lindjes, dasmës dhe vdekjes. [Rites of Birth, Wedding and Funeral.] Durrës: Pavarësia.

Denny, Frederick Mathewson n.d. Circumcision. In: Jane Dammen McAuliffe (ed.) Encyclopaedia of the Qur'ān. Online edition. http://dx.doi.org/10.1163/18753922_q3_EQSIM_00079.

Elbasani, Arolda \& Roy, Olivier (eds.) 2015. The Revival of Islam in the Balkans: From Identity to Religiosity. London: Palgrave Macmillan.

Gennep, Arnold van 2004 [1909]. Rites of Passage. London \& New York: Routledge.

Ivanova, Iuliia 1973. Severnaia Albaniia v XIX-nachale XX v. Obshchestvennaia zhizn'. [Northern Albania in the 19th - Early 20th Centuries. Public Life.] Moscow: Nauka.

Karpov, Iurii 1996. Dzhigit i volk: Muzhskie soiuzy v sotsiokul'turnoi traditsii gortsev Kavkaza. [Dzhigit and the Wolf: Men's Unions in the Sociocultural Tradition of the Highlanders of the Caucasus.] St. Petersburg: MAE RAN.

Karpov, Iurii 2001. Zhenskoe prostranstvo v kul'ture narodov Kavkaza. [Female Space in the Culture of the Peoples of the Caucasus.] St. Petersburg: Peterburgskoe vostokovedenie. Available at https://rusneb.ru/catalog/000199_000009_000717505/, last accessed on 15 October 2020.

Krieger, John N. 2012. Male Circumcision and HIV Infection Risk. World Journal of Urology, Vol. 30, No. 1, pp. 3-13. https://doi.org/10.1007/s00345-011-0696-x.

Novik, Aleksandr 2016. Svad'ba i traditsii braka u albantsev Ukrainy. [Wedding and Marriage Traditions of the Albanians of Ukraine.] In: A. Novik \& Y. Buchatskaia \& D. Ermolin \& A. Dugushina \& M. Morozova (comps.) "Priazovskii otriad": Iazyk i kul'tura albantsev Ukrainy. Part I, Vol. 1. St. Petersburg: MAE RAN, pp. 586-726. Available at http://ib.kunstkamera.ru/files/lib/978-5-88431-313-2/978-5-88431313-2_11.pdf, last accessed on 15 October 2020.

Novik, Aleksandr 2017. "Gornyi chai", shalfei, chai, romashka i kofe v traditsii, narodnoi meditsine i etikete albantsev i grekov Khimary i Dropula. ["Mountain Tea", Sage, Tea, Chamomile and Coffee in the Tradition, Traditional Medicine and Etiquette of the Albanians and Greeks of Himara and Dropul.] Acta Linguistica Petropolitana. Trudy Instituta lingvisticheskikh issledovanii, Vol. XIII, Part 2: Etnobotanika 2: Rasteniia v iazyke i kul'ture, pp. 116-131. Available at https:// alp.iling.spb.ru/static/alp_XIII_2.pdf, last accessed on 15 October 2020.

Novik, Aleksandr \& Rezvan, Efim 2019. Islam na Balkanakh. Chast'I. Obriady perekhoda i semeinaia obriadnost': rozhdenie, obrezanie: uchebnoe posobie. [Islam in the Balkans. Part I. Rites of Passage and Family Rituals: Birth, Circumcision: A Training Manual.] St. Petersburg: Izdatel'stvo SPbGU.

Nussbaum, Martha C. 2000 [1999]. Sex and Social Justice. New York \& Oxford: Oxford University Press. 
Oren (Nadel'), Itskhak \& Prat, Naftali (eds.) 1992. Obrezanie. [Circumcision.] In: Itskhak Oren (Nadel') \& Naftali Prat (eds.) Kratkaia evreiskaia entsiklopediia. Vol. 6. Jerusalem: The Hebrew University of Jerusalem, pp. 39-42. Available at https://eleven.co.il/judaism/commandments-and-precepts/13031/, last accessed on 15 October 2020.

Sedakova, Irina 2007. Balkanskie motivy v iazyke i kul'ture bolgar: Rodinnyi tekst. [Balkan Motifs in Bulgarian Language and Culture: Birthlore.] Moscow: Indrik. Available at https://inslav.ru/publication/sedakova-i-balkanskie-motivy-v-yazykei-kulture-bolgar-rodinnyy-tekst-m-2007, last accessed on 15 October 2020.

Shell-Dunkan, Bettina \& Hernlund, Ylva 2004. Female Genital Cutting: Social and Cultural Dimensions of the Practice and the Debates. In: Carol R. Ember \& Melvin Ember (eds.) Encyclopedia of Medical Anthropology. Vol. 1: Topics. New York: Springer, pp. 252-262. https://doi.org/10.1007/0-387-29905-X_30.

Sulaj, Elsa (ed.) 2013. Bimët Mjekësore - Instituti i shkencave - 1980. [Medicinal Plants Institute of Sciences - 1980.] Tirana: Shtëpia botuese: Akademia e Shkencave dhe e Arteve e Kosovës.

Wensinck, Arent Jan 1986. Khitān. In: Encyclopaedia of Islam. Vol. 5. Leiden: E. J. Brill, pp. 20-22. Available at https://referenceworks.brillonline.com/browse/ encyclopaedia-of-islam-2/alphaRange/Kh\%20-\%20Kn/K?s.start=240, last accessed on 15 October 2020.

Xhagolli, Agron 2008. Synetia ndër shqiptarë. [Circumcision among Albanians.] Kultura popullore, Vol. 1-2, pp. 21-37.

Zojzi, Rrok 1962. Ndamja krahinore e popullit shqiptar. [Regional Division of the Albanian People.] Etnografia Shqiptare, Vol. 1, pp. 16-64.

\section{ARCHIVAL SOURCES}

AMAE - Archive of Peter the Great Museum of Anthropology and Ethnography (Kunstkamera) of the Russian Academy of Sciences, St. Petersburg, Russia:

AMAE: Novik 2010 = Novik, Aleksandr 2010. Kosovo: Traditsionnaia kul'tura albantsev Kosovo. 15.08-28.08.2010. Polevaia tetrad'. Avtograf. [Kosovo: The Traditional Culture of the Albanians of Kosovo. 15.08.-28.08.2010. Field notebook. Autograph.] Collection K-1, aids 2, No. 1987, 23 pp.

AMAE: Novik 2013 = Novik, Aleksandr 2013. Kosovo: Traditsionnaia kul'tura albantsev Kosovo, iuvelirnoe delo, albantsy i slaviane. Polevye zapisi. Avtograf. 19.08.30.08.2013. [Kosovo. The Traditional Culture of the Albanians of Kosovo, Jewelry, Albanians, and Slavs. Field notes. Autograph. 19.08-30.08.2013.] Collection K-1, aids 2 , No. 2179, 36 pp.

AMAE: Novik 2015 = Novik, Aleksandr 2015. Kosovo. Traditsionnaia kul'tura albantsev Kosovo, iuvelirnoe delo, albantsy i slaviane. Polevye zapisi. Avtograf. 16.0830.08.2015. [Kosovo: The Traditional Culture of the Albanians of Kosovo, Jewelry, Albanians and Slavs. Field notes. Autograph. 16.08-30.08.2015.] Collection K-1, aids 2 , w/no., $32 \mathrm{pp}$. 


\title{
INTERVIEW MATERIALS
}

FWMA 1987 - Fieldwork materials of the author. Ukraine, 1987.

FWMA 2009 - Fieldwork materials of the author. Albania, Kosovo, 2009.

FWMA 2014 - Fieldwork materials of the author. Albania, Kosovo, Montenegro, 2014.

FWMA 2015 - Fieldwork materials of the author. Albania, Kosovo, Montenegro, 2015.

FWMA 2016 - Fieldwork materials of the author. Albania, Kosovo, Montenegro, 2016.

FWMA 2019 - Fieldwork materials of the author. North Macedonia, Albania, Kosovo, 2019 .

\section{INTERNET SOURCES}

Circumcision n.d. MedlinePlus.gov. U. S. National Library of Medicine. Available at https://medlineplus.gov/ency/article/002998.htm, last accessed on 14 October 2020 .

Zero Tolerance n.d. = International Day of Zero Tolerance for Female Genital Mutilation, 6 February. Un.org. Available at https://www.un.org/en/observances/femalegenital-mutilation-day, last accessed on 15 October 2020.

Female genital mutilation 2020. Who.int, 3 February. Available at https://www.who. int/news-room/fact-sheets/detail/female-genital-mutilation, last accessed on 15 October 2020.

Prazdnik $2006=$ Prazdnik obrezaniia gospodnia [Feast of the Circumcision of the Lord.] 2006. Pravoslavie.ru, 14 January. Available at http://www.pravoslavie.ru/2040. html, last accessed on 15 October 2020.

The Noble Qur'an n.d. Available at https://quran.com, last accessed on 14 October 2020.

\begin{abstract}
Alexander Novik is PhD, Head of the Department of European Studies, Peter the Great Museum of Anthropology and Ethnography (Kunstkamera) of the Russian Academy of Sciences, and Associate Professor in Albanian Philology and Balkan Ethnology at the Department of General Linguistics, Saint Petersburg State University, Saint Petersburg, Russia. His research interests are in the field of traditional and modern culture, ethnolinguistics, ethnic and religious minorities, folk costume, and festivity.

njual@mail.ru
\end{abstract}

